\title{
Temporal and Propositional De Se: Evidence from Romanian SUBJUNCTIVE MOOD ${ }^{1}$
}

\author{
Adrian Brasoveanu, \\ Rutgers University and University of Frankfurt \\ abrsvn@eden.rutgers.edu
}

\begin{abstract}
The paper investigates the interpretation of the Romanian subjunctive B (subjB) mood when it is embedded under the propositional attitude verb crede (believe). SubjB is analyzed as a single package of three distinct presuppositions: temporal de se, dissociation and propositional de se. I show that subjB is the temporal analogue of null PRO in the individual domain: it allows only for a de se reading. Dissociation enables us to show that subjB always takes scope over a negation embedded in a belief report. Propositional de se derives this empirical generalization. The introduction of centered propositions (generalizing centered worlds), together with propositional de se, dissociation and the belief 'introspection' principles, derives the fact that subjB belief reports (unlike their indicative counterparts) are infelicitous with embedded probabil.
\end{abstract}

\section{Introduction}

This paper is a systematic exploration of the interpretation of the Romanian subjunctive B mood when it is embedded under the propositional attitude verb crede (believe) ${ }^{2}$. Subjunctive B - traditionally labeled 'conditional-optative' - is one of the two subjunctive (i.e. nonindicative finite) moods in Romanian. As the example in (1) below shows, it is morphologically realized as an auxiliary verb that agrees in person and number with the subject.

$$
\text { Maria crede că ar fi în pericol. }
$$

Mary believe.ind.pres.3s that subjB.3s be in danger.

Mary believes that she is in danger.

I analyze subjunctive $\mathrm{B}$ as a bundle of three distinct presuppositions: (a) temporal de se, (b) dissociation and (c) propositional de se. Consider example (1) above: temporal de se means that the reported belief of being in danger is temporally located at the internal now of the believer, i.e. at the time which Mary (correctly or not) takes her 'present' to be. Dissociation basically means that the speaker dissociates herself from the reported belief, i.e. as far as the

\footnotetext{
${ }^{1}$ Acknowledgements: I am greatly indebted to Maria Bittner, Sam Cumming, Hans Kamp, Oana SăvescuCiucivara, Roger Schwarzschild, Adam Sennet, Magdalena Schwager, Matthew Stone and Ede Zimmermann for extensive discussion of the issues addressed here. I want to thank the Sinn und Bedeutung 10 abstract reviewer(s) for their very helpful comments. I am also indebted to the following people for discussion: Agnes Bende-Farkas, Alexandra Cornilescu, Veneeta Dayal, Carmen Dobrovie-Sorin, Donka Farkas, Kai von Fintel, Jane Grimshaw, Nathan Klinedinst, Angelika Kratzer, Cécile Meier, Jessica Rett, Uli Sauerland, Oana Săvescu-Ciucivara, Philippe Schlenker, Ted Sider, Satoshi Tomioka, Violeta Vazquez-Rojas Maldonado, Hong Zhou, Eytan Zweig and the SURGE (Sept. 2005), GK Frankfurt Colloquium (Oct. 2005) and Sinn und Bedeutung 10 (Oct. 2005) audiences. I want to thank Carmen Dobrovie-Sorin, Andreea Grigorean, Simona Herdan, Mihai Ignat, Cristian Lupu and Oana Săvescu-Ciucivara for the Romanian judgments and Sam Cumming, Jessica Rett, Roger Schwarzschild and Adam Sennet for the English judgments. The support of a DAAD grant during the last stages of this investigation is gratefully acknowledged. The usual disclaimers apply.

${ }^{2}$ There seem to be dialectal differences in the use of subjB with the verb crede: one of the native speakers I have consulted does not readily accept sentences like (1) above.
} 
speaker is concerned, it could be the case that Mary is not in danger, even though Mary herself thinks that she is.

Finally, propositional de se means that the believer has an attitude towards a 'self-referential' kind of content similar to the self-referential experience contents proposed by Searle $(1983)^{3}$. For example, the content of my visual experience of seeing a yellow station wagon is that: (a) there is a yellow station wagon there and (b) the fact that there is a yellow station wagon there is causing this very visual experience. This 'self-referentiality' is the expression of the common sense intuition that having an experience or an attitude is assuming a particular point of view / perspective on the content of the experience or of the attitude.

Intuitively, a belief report with subjunctive $\mathrm{B}$ mood is propositionally de se insofar it explicitly encodes in the believed content this perspectival component inherent in any attitude; the form of such a report is basically: $x$ has a belief $p$ that the embedded clause is true and $x^{\prime} s$ belief $p$ is such that the proposition expressed by the embedded clause is true in any world $w$ in $p$. This makes a subjunctive B report 'self-referential' in Searle's sense and also redundant, since the commitment of the attitude holder to the proposition expressed by the embedded clause is stated twice. However, the redundancy is crucial in deriving two unexpected empirical generalizations: (a) if the believed proposition has a negative form, e.g. $x$ believes that not $q$, then subjunctive $\mathrm{B}$ has to have wide-scope with respect to negation; this is a consequence of the fact that, on the narrow-scope reading, the subjunctive B report is contradictory: it has the form $x$ believes that not $q$ (on the one hand) and $q$ is what $x$ believes (on the other hand); (b) moreover, subjunctive B reports with probabil (probably) of the form $x$ believes that probably $q$ are not felicitous, unlike their indicative counterparts; this is due to the fact that subjunctive B requires complete commitment to proposition $q$, while probably implicates that there is at most a partial commitment.

The structure of the paper is the following. In section 2, I argue that the contrast between indicative and subjunctive B in Romanian is parallel to the contrast between overt pronouns (e.g. John hopes that he will win) and null PRO (e.g. John hopes to win) in the individual domain. As Chierchia (1989) and Schlenker (2003) observe, overt pronouns are compatible with both the de se and non-de se readings, while null PRO allows only for a de se reading. The proposal is that subjunctive $\mathrm{B}$ is parallel to PRO in that it requires a temporally de se reading, while indicative is parallel to overt pronouns because it can, but does not have to receive such a reading.

In section 3, I expand on the brief observation in Farkas (1992) that subjunctive B has a dissociation component. I argue that dissociation is a presupposition (as opposed to e.g. a conventional implicature) based on its projection behavior in negative contexts and 'stacked' attitude reports of the form $x$ wants $y$ to believe that $p$. I end the section with the generalization that sets the stage for propositional de se: subjunctive $\mathrm{B}$ always has wide-scope with respect to an embedded negation, e.g. in belief reports of the form $x$ believes that not $p$, the speaker always dissociates herself from not $p$ and never from $p$, despite the fact that, on the surface, the subjunctive B morpheme is always placed between not and $p$.

Section 4 proposes a semantic solution to the wide-scope problem (as opposed to syntactically stipulating the wide-scope and attempting to justify the syntactic assumption on independent grounds): subjunctive $\mathrm{B}$ is propositional de se in the sense suggested above. This solution extends the de se vs. non-de se contrast between subjunctive $\mathrm{B}$ and indicative from the temporal to the modal domain and thus makes for an attractive overall analysis: we extend the parallel between pronouns, tenses and moods, pursued in Partee (1973), Abusch (1997), Stone (1999) and Schlenker (2003) among others, to de se readings. The propositional de se hypothesis also derives the incompatibility between subjB and probably if we assume the

\footnotetext{
${ }^{3}$ Matthew Stone suggested this parallel (p.c.).
} 
belief introspection principles ${ }^{4}$, which effectively reduce iterated belief ( $x$ believes that $x$ believes that $p$ ) to non-iterated belief ( $x$ believes that $p$ ).

The concluding section 5 briefly discusses whether the three components of the subjunctive B interpretation are independent.

\section{Subjunctive $B$ as temporal de se}

In this section, I first review de se and de re beliefs in the individual domain and sketch the way Lewis (1979) analyzes them. In particular, I focus on the contrast between overt pronouns and null PRO in non-de se 'mistaken identity' scenarios, which was noticed in Chierchia (1989) and Schlenker (2003) among others (2.1). Based on a 'mistaken temporal identity' scenario, I establish that the Romanian subjunctive B mood has to be interpreted temporally de se, just like PRO has to be interpreted individually de se (2.2).

\subsection{De se and de re belief in the individual domain}

The Kaplanian sentence in (2) below can receive two distinct interpretations.

Neo believes that his pants are on fire.

Under the first - de se - interpretation, Neo is saying to himself "My pants are on fire" and he is therefore very likely to run for the fire extinguisher.

To see the second - non-de se - interpretation, consider the following scenario: Neo is looking in a mirror without realizing it. He is seeing a man whose pants are on fire, which is in fact Neo himself, but he does not realize that either; (2) can be truthfully asserted in this situation, but it receives a different interpretation, as witnessed by Neo's possibly different behavior: if Neo is in a particularly mean mood, he might very well just stand there and enjoy the show (at least until the situation gets hot enough for him to realize his misunderstanding).

Under the de se interpretation, (2) reports Neo's belief that someone's pants are on fire, where that someone is the belief-internal self, i.e. whoever Neo takes himself to be. Under the nonde se (but de re) interpretation, (2) reports Neo's belief that someone's pants are on fire, where that someone is the guy that Neo is looking at, whoever that may be.

The analysis of de se and de re belief in Lewis (1979) involves three ingredients: (a) centered worlds: the believed content is not a proposition, i.e. a set of worlds (as the standard analysis would have it $^{5}$ ), but a property, or, equivalently, a set of centered worlds ${ }^{6}$; a centered world is a pair $\left(w, x^{\text {self }}\right)$, where $w$ is a world and $x^{\text {self }}$, the center of world $w$, is the unique individual that Neo takes himself to be in $w$, i.e. the belief-internal 'self'; (b) self ascription: the verb believe is interpreted as a relation between an individual and a set of centered worlds (and not as a relation between an individual and a proposition); that is, we replace the function $\boldsymbol{d o x}_{w^{*}, x^{*}}$ that returns a set of worlds (the set of $x^{*}$ 's doxastic alternatives to $w^{*}$ ) with a function self_ascribe $w_{w^{*}, x^{*}}$, which returns a set of centered worlds $\left(w, x^{\text {self }}\right)$; (c) acquaintance relations: the reported belief is about an individual with whom the belief-internal 'self' is acquainted in a particular way; in the de se case, the acquaintance relation is the most intimate relation the belief-internal 'self' can have with any individual whatsoever, namely the identity relation; in the non-de se (but de re) case, the acquaintance relation is the causal relation established between the belief-internal 'self' and whoever it is that he is looking at (see Lewis (1979): 539).

\footnotetext{
${ }^{4}$ See Hintikka (1962) for an early discussion.

${ }^{5}$ See for example Hintikka (1969).

${ }^{6}$ See for example Creswell \& von Stechow (1982) for more discussion.
} 
Thus, independently of other presuppositional features like gender or number, the pronoun his in (2) is triply context dependent: (a) it presupposes access to an acquaintance relation; (b) it is anaphoric to the real individual that the believer is acquainted to in the actual world; (c) it is dependent on the internal 'self' of the believer.

The de re but non-de se reading of (2) is given in (3) below.

(3) De re (non-de se): Neo's centered belief worlds $\left(w, x^{\text {self }}\right)$ are such that, given the unique individual $x$ the belief-internal 'self' (i.e. $x^{\text {self }}$ ) is looking at, $x^{\prime}$ s pants are on fire in $w$.

The de se reading of (2) is given in (4) below.

(4) De se: Neo's centered belief worlds $\left(w, x^{\text {self }}\right)$ are such that, given the unique individual $x$

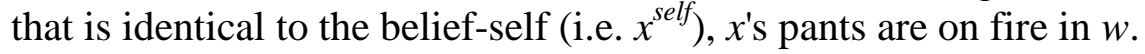

Moreover, as Chierchia (1989) and Schlenker (2003) (among others) observe, the morphological form of the pronoun can distinguish between the two readings: overt pronouns like he in (5a) below are compatible with both the de se and non-de se readings, while the null PRO in (5b) allows only for a de se reading ${ }^{7}$.

a. Neo hopes that he will win.

b. Neo hopes PRO to win.

To see this, consider the following de se and non-de se scenarios (based on Schlenker (2003)): (a) de se: young Neo participates in a singing competition; after his performance, he tells one of his friends: "I hope I'll win"; (b) non-de se 'mistaken identity' scenario: young Neo participates in a singing competition; after his performance, he relaxes with one too many glasses of wine; accidentally, he listens to a recording of his own performance but doesn't realize that and he says: "I hope this guy will win". Both the overt pronoun in (5a) and PRO in (5b) are felicitous in the de se context, but only the overt pronoun in (5a) is felicitous in the non-de se context.

\subsection{De se and non-de se belief in the temporal domain}

In this section, I show that the contrast between subjunctive B (subjB) and indicative (ind) in Romanian is the temporal analogue ${ }^{8}$ of the contrast between PRO and overt pronouns in the individual domain. SubjB is the temporal analogue of PRO, since it requires a de se interpretation, in contrast to indicative, which, like an overt pronoun, can but does not have to receive a de se interpretation. Consider the 'mistaken temporal identity' scenario in (6) below.

(6) John is a very gullible tabloid reader: whatever a tabloid says, he believes. A Monday tabloid said that the Martians were going to invade Bucharest on Thursday, i.e. three days later. On Thursday, the day of the invasion, John and I talked about this issue. But John was confused: he thought it was Wednesday when, in fact, it was Thursday.

In this context, the indicative report in (7a) is (more or less) felicitous, while the subjB report in $(7 b)$ is not.

(7) Cînd m-am întîlnit cu el, Ion (de fapt) credea că...

When I met him, John (in fact) believed that...
a. ?marţienii
invadează
Bucureștiul în ziua aceea.
Martians.the
invade.ind.pres Bucharest.the in day that.

\footnotetext{
${ }^{7}$ For more discussion, see Chierchia (1989): 14 et seqq.

${ }^{8}$ Lewis (1979): 530-531 already observes that there is such a thing as a temporally de se attitude.
} 


\section{b. \#marțienii ar invada Bucureştiul în ziua aceea. \\ Martians.the subjB invade Bucharest.the in day that. \\ the Martians were invading Bucharest that day.}

The scenario in (6) and the examples in (7) are parallel to the individual de se 'mistaken identity' scenarios and examples because, just as Neo hopes that he will win without realizing that his hopes are about himself - in which case the overt pronoun he is acceptable, but PRO is not - , John believes that the Martian invasion happens the very day of the conversation, without actually realizing the imminence of the alien takeover - in which case indicative is acceptable, while subjunctive $B$ is not.

The analysis of temporal de se / de re is parallel to the analysis of individual de se / de re. Just as in Abusch (1997), we extend centered worlds with a variable for time: the individual john is self-ascribing in world $w^{*}$ at time $t^{*}$ a set of centered worlds $\left(w, x^{\text {self }}, t^{\text {now }}\right)$, where $x^{\text {self }}$ is the unique individual that john takes himself to be in $w$ and $t^{\text {now }}$ is the unique time that john takes its internal 'now' to be in $w$. Moreover, we will have acquaintance relations relative to time intervals: for example, in (7a) above, John has a non-de se acquaintance relation to the following Thursday as "the day the tabloid said the Martians would invade Bucharest" ${ }^{\text {9 }}$ and, in (7b), a de se acquaintance relation with the day of his internal now, which he believes is a Wednesday (while in the actual world it is in fact Thursday).

The two readings of the belief report in (7) are given in (8) and (9) below.

(8) Non-de se: John's centered belief worlds $\left(w, x^{\text {self }}, t^{\text {now }}\right)$ are such that, given the unique day $t$ that the tabloid specified in $w$, the Martians are invading Bucharest at $t$ in $w$.

De $s e^{10}:$ John's centered belief worlds $\left(w, x^{\text {self }}, t^{\text {now }}\right)$ are such that, given the unique day $t$ that is the day of $t^{\text {now }}$ in $w$, the Martians are invading Bucharest at $t$ in $w$.

Since the indicative in (7a) can receive the interpretation in (8), the belief report is felicitous, while the subjunctive $\mathrm{B}$ report in $(7 \mathrm{~b})$ is not, because subjunctive $\mathrm{B}$ can receive only the de se interpretation in (9), which is false in the given context. Thus, we discovered that the temporal de se vs. non-de se contrast is mirrored in the morphology of belief reports just as the individual de se vs. non-de se contrast is ${ }^{11}$.

\footnotetext{
${ }^{9}$ But not exactly de re, if we assume that de re relations have to involve causal connections: how can John be causally acquainted on a Monday with the following Thursday? See Abusch (1997) for some discussion.

${ }^{10}$ Note that temporal de se belief is belief under the acquaintance relation of inclusion (the day of $t^{\text {now }}$ is the day in which $t^{\text {now }}$ is included), unlike individual de se, where the acquaintance relation is that of identity.

${ }^{11}$ The hypothesis that subjB is temporally de se seems to be contradicted by the fact that subjB can be part of constructions of the form subjB + auxiliary $\mathrm{BE}+$ past participle of the verb - which receive a perfective reading - in addition to the constructions mentioned above of the form subjB + bare verb, as shown in (i) below.

(i) Ion tocmai şi - a terminat de scris lucrarea de licență.

John has just finished writing his undergrad thesis.

Maria crede că Ion ar fi scris o capodoperă.

Mary believe.ind.pres.3s that John subjB.3sg BE written a masterpiece.

Mary believes that John wrote / has written a masterpiece.

We can maintain that subjB is temporally de se if we analyze the construction BE+ppart similarly to the way Kamp \& Reyle (1993): 556 et seqq. analyze the English perfective have written: the auxiliary BE contributes an eventuality of its own (a state, but not a result state as the English have) which is temporally located at the internal now of the attitude; the completed eventuality contributed by the lexical verb is temporally located before the state contributed by BE. An independent argument for the subjB+BE+ppart construction being temporally de se is provided by present attitude reports towards a future eventuality: as the examples in (iia) and (iib) below show, the indicative anterior future is felicitous in such situations, but not subjB+BE+ppart.

(ii) Ion a plecat ieri în Australia. Maria crede că în şase luni ...
}

John left for Australia yesterday. Mary believe.ind.pres.3s that in six months...

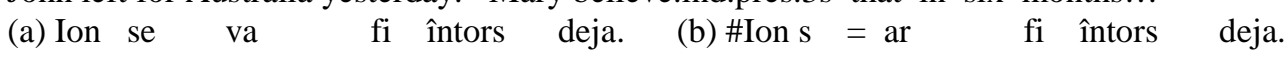
John SE ind.fut.3s $B E$ returned already. John $\mathrm{SE}=\operatorname{subjB} .3 \mathrm{~s} B E$ returned already. Mary believes that in six months John will have already come back. 


\section{Subjunctive B: dissociation}

In this section, we turn to the second presuppositional component of subjunctive $\mathrm{B}$, namely dissociation, which was first noticed in Farkas (1992): $82^{12}$. Dissociation means that in a report of the form $x$ believes that $p$, where $p$ is marked with subjunctive $\mathrm{B}$, the speaker dissociates herself from $p$, i.e. the speaker has reason to believe that $p$ might be false. In general, a speaker $a$ dissociates herself from a proposition $p$ iff there is at least one world $w$ among $a$ 's doxastic alternatives in which $p$ is false. Thus, dissociation simply means that the speaker and the attitude holder do not agree on proposition $p$ and not the stronger requirement that the speaker believes not $p$. In 3.1, I provide several diagnostics for dissociation and briefly indicate how dissociation is represented. In 3.2, I argue that dissociation is presuppositional based on its projection behavior in negative contexts and 'stacked' attitude reports of the form $x$ wants $y$ to believe that $p$ (the projection facts in conditionals are omitted for space reasons). Finally, in 3.3, I establish the generalization that sets the stage for propositional de se: subjB always has wide-scope with respect to embedded negation.

\subsection{Diagnostics for dissociation}

Once again, we contrast indicative and subjunctive B.

(10) Ion îşi scrie lucrarea de licență. Maria crede că ...

John is writing his undergrad thesis. Mary believes that...
a. Ion scrie
o capodoperă. $\sqrt{ }$ IND
b. Ion ar scrie o capodoperă. $\sqrt{ }$ SUBJB John write.ind.pres a masterpiece. John subjB write a masterpiece.

The indicative report in (10a) is neutral with respect to the speaker's attitude, while the subjB report in (10b) expresses, in addition to what (10a) does, that the speaker does not also believe John's thesis to be a masterpiece, i.e. as far as the speaker is concerned, it could be a piece of junk (although the speaker does not necessarily believe that it is junk).

This intuition is supported by the fact that first-person belief reports with indicative are felicitous, while subjB reports are not. This contrasts with the third-person reports in (10) above, where both indicative and subjB are felicitous ${ }^{13}$.
Cred
că Maria este
/ \# ar fi
bolnavă. IND / \#SUBJB
Believe.ind.pres.1s that Mary be.ind.pres / \#subjB be sick.
I believe that Mary is sick.

Another argument for dissociation is the infelicity of subjunctive B with factive verbs like şti (know) or regreta (regret), as shown by (12) below.
Ion ş̧ie / regretă că Maria este
/ \#ar
fi bolnavă. VIND / \#SUBJB
John knows / regrets that Mary be.ind.pres / \#subjB be sick.

Dissociation is supported by the infelicity of subjB with factive verbs because factive verbs presuppose that the reported belief is true throughout the current Context Set (see Stalnaker

\footnotetext{
12 "In Romanian, in the case of declaratives, the conditional is used to indicate 'speaker reservation' with respect to the truth of the complement [...] Note that the use of a non-indicative in the complements of declaratives does not commit the speaker to a negative valuation of the propositional content of the complement; the nonindicative mood simply stresses that the speaker is not committed to a positive valuation. The complement is therefore not counterfactual, but rather 'afactual' as far as the speaker is concerned." (Farkas (1992): 82)

${ }^{13}$ First-person belief reports with subjunctive B are felicitous in the following kind of context: I am trying to objectively present a debate between me and John to a third party, e.g. to an audience of people asked to judge for themselves whether the Romanian subjunctive B is de se or not. In that case, I can utter:

(i) Ion crede că subjonctivul B în română nu ar fi de se, dar eu cred că ar fi de se.

John believes that the Romanian subjunctive B is (subjB) not de se, but I believe it is (subjB) de se.
} 
(1978) for this notion) and the speaker belief-worlds are always a subset of the Context Set since all the propositions in the Common Ground have already been accepted by all participants in the conversation. Therefore, if the speaker already accepted the proposition that Mary is sick, she cannot dissociate herself from it, as the subjB in (12) requires ${ }^{14}$.

Finally, dissociation is supported by the distribution of indicative and subjB in the three kinds of contexts listed in (13) below; (13a) says that, in a context in which $\neg p$ is true, we can felicitously assert $x$ believes $p$, where $p$ is marked with either indicative or subjB - and the same goes for (13b), where the Context Set endorses neither $p$ nor $\neg p$. The only context that distinguishes between indicative and $\operatorname{subjB}$ is the one in (13c): if $p$ is true throughout the Context Set (hence, the speaker also believes $p$ ), only the indicative report is felicitous.
a. $\neg p$;
$x$ believes $p$
$\sqrt{ } \mathbf{I N D} ; \quad \sqrt{ } \mathbf{S U B J B}$
b. $\operatorname{possible}(p) \& \operatorname{possible}(\neg p) ; \quad x$ believes $p$
$\sqrt{I N D} ; \sqrt{\text { SUBJB }}$
c. $p$
$x$ believes $p$
$\sqrt{ }$ IND; \#SUBJB

I give the actual data only for the last case.

(14) (Eu cred că) Maria este urîtă. Ion crede că Maria este / \#ar fi urîtă. VIND / \#SUBJB (I believe that) Mary is ugly. John believes that Mary is ugly.

I represent dissociation as a condition $w \notin p$, i.e. there is at least one witness world $w$ among the speaker belief worlds - hence, among the current Context Set worlds - such that the reported belief $p$ is not true in $w$. The tree in (15) below gives the basic structure of the logical form for (1): subjB requires there to be at least one world $w$ in CS (the Context Set) in which $p$ is false and this requirement 'percolates' all the way to the top of the tree.

Mary believes that she is (subjB - dissociation) in danger.

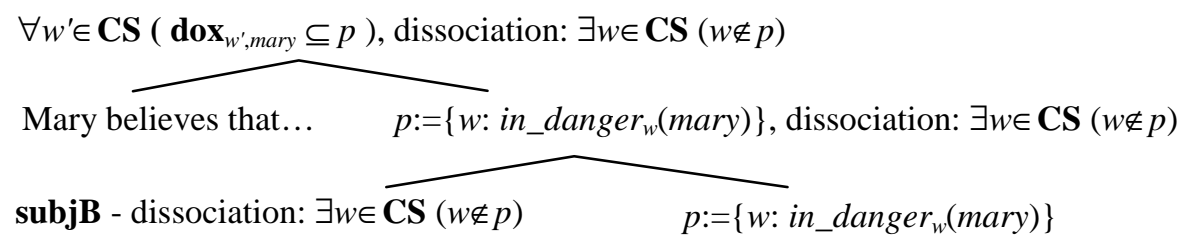

The 'percolation' of the dissociation requirement $\exists w \in \mathbf{C S}(w \notin p)$ to the top of the tree is consistent with the presuppositional nature of dissociation, to which we now turn.

\subsection{Dissociation is presuppositional}

The fact that dissociation is presuppositional is shown by its projection behavior in negative contexts, conditionals and 'stacked' attitude reports of the form $x$ wants $y$ to believe that $p$ (for space reasons, I do not provide the data for conditionals). A negative expression of the form $N u$ este adevărat că... (It is not the case that...), when added on top of a subjB belief report of the form $x$ crede că $p$ ( $x$ believes that $p$ ) is transparent, i.e. a 'hole', for dissociation.

\footnotetext{
${ }^{14}$ It follows from these observations that matrix declarative sentences marked with subjB are infelicitous. In fact, they are not - but a subjB matrix clause like the one in (i) below can be interpreted only: (a) as expressing Mary's desire to go to the movies or (b) as the consequent of a covert conditional (hence the traditional labeling of subjunctive B as 'conditional-optative'). Either way, (i) cannot be interpreted as asserting the proposition that Mary is going to the movies - as its indicative counterpart does.

(i) Maria ar merge la film.

Mary subjB go to movie.

Mary would like to go to the movies / [If the theater weren't that far], Mary would go to the movies.
} 
(16) $\neg p$; it is not the case that $x$ believes $p$

$\sqrt{\text { SUBJB }}$

Maria nu este în pericol. (Şi) Nu este adevărat că Maria crede că ar fi în pericol.

Mary is not in danger. (And) It is not the case that Mary believes that she is in danger.

$p$; it is not the case that $x$ believes $p$

\#SUBJB

Maria este în pericol. \#(Dar) Nu este adevărat că Maria crede că ar fi în pericol.

Mary is in danger. \#(But) It is not the case that Mary believes that she is in danger.

Finally, the projection behavior of dissociation in 'stacked' attitude reports of the form $x$ wants $y$ to believe that $p$ also shows that dissociation is presuppositional: unlike conventional implicatures ${ }^{15}$, the dissociation requirement does not have to be resolved relative to the speaker belief-worlds, but can be resolved relative to the belief-worlds of the higher attitude holder, e.g. $x$ 's belief-worlds in the 'stacked' report $x$ wants $y$ to believe that $p^{16}$. Thus, the initial characterization of dissociation as a speaker-oriented requirement is an oversimplification, which I have upheld for expository reasons. Consider the scenario in (18).

(18) Both Mary and Helen like John and they are jealous of each other. A couple of days ago, Helen suddenly decided to leave LA for a trip - and she left that very day.

In this context, the discourse in (19), in particular the subjB report in $\left(19^{2}\right)$, is felicitous.
${ }^{1}$ Maria crede în mod greșit că...
Elena este încă în LA,
Mary mistakenly believes that...
Helen is (ind) still in LA,
${ }^{2}$ dar vrea ca Ion să creadă că...
Elena nu ar fi în LA.
but she wants John to believe that... Helen is (subjB) not in LA.

(IND)

$\sqrt{ }$ SUBJB

Since the speaker knows that Helen is not in LA, the dissociation triggered by the subjB in $\left(19^{2}\right)$ cannot be resolved relative to the speaker's belief-worlds. However, subjB is felicitous because Mary's belief worlds can satisfy the dissociation requirement ${ }^{17}$.

\subsection{The relative scope of subjunctive $B$ and embedded negation}

The dissociation requirement allows us to pinpoint the relative scope of subjB with respect to embedded negation and embedded negative quantifiers. We have distinct dissociation presuppositions if subjB has wide scope with respect to negation ( $\mathbf{s u b j B}>>\mathbf{n o t}>>p$ ) and if subjB has narrow scope (not $>>\mathbf{s u b j B}>>p$ ). In the wide-scope case, subjB dissociates from not $p$, i.e. for some $w$ in the Context Set, $w \notin \neg p$; in the narrow-scope case, subjB dissociates from $p$, i.e. for some $w$ in the Context Set, $w \notin p$. Only the wide-scope dissociation is empirically attested - despite the overt surface form, in which negation precedes (and has to precede) the subjB morpheme. The data is provided in (20) and (21) below.

$p ; x$ believes not $p$.

${ }^{1}$ Maria este în pericol. ${ }^{2}$ (Dar) Maria crede că

$\checkmark$ SUBJB

Mary is in danger.

(But) Mary believes that

nu ar fi în pericol.

not subjB be in danger.

\footnotetext{
${ }^{15}$ For the distinction between presuppositions and conventional implicatures, see Potts (2004).

${ }^{16}$ Propositional attitude verbs like want, fear etc. are filters for the presuppositions of the embedded sentence: they have to be satisfied by the belief-worlds of the attitude holder (in the given local context). As Heim (1992): 183, following Karttunen, puts it, "if $\sigma$ is a verb of propositional attitude, then a context c satisfies the presuppositions of ' $\alpha \sigma \varphi$ ' only if $\mathrm{B}_{\alpha}(\mathrm{c})$ satisfies the presuppositions of $\varphi$; where ' $\mathrm{B}_{\alpha}(\mathrm{c})$ ' stands for the set of beliefs attributed to $\alpha$ in c". For example, John wants the king of France to get bald does not presuppose that John wants it to be the case that there is a unique king of France, but that John believes that there is a unique king of France.

${ }^{17}$ As expected, if we embed first-person belief reports in structures like the one in (19), they are also felicitous:
}

(i) ${ }^{1}$ Maria crede în mod greşit că... $\quad$ Elena este încă în LA,

Mary mistakenly believes that... Helen is (ind) still in LA,

${ }^{2}$ dar vrea ca eu să cred că... $\quad$ Elena nu ar fi în LA.

(IND)

but she wants me to believe that... Helen is (subjB) not in LA. 
(21) $\quad \operatorname{not} p ; x$ believes not $p$.

\#SUBJB

${ }^{1}$ Maria nu este în pericol. ${ }^{2}$ \#(Şi) Maria crede că nu ar fi în pericol.

Mary is not in danger. \#(And) Mary believes that not subjB be in danger.

In a context in which $p$ is true (as in (20)), the wide-scope dissociation from not $p$ is satisfied - hence subjB is felicitous; in a context in which not $p$ is true (as in (21)), the narrow-scope dissociation from $p$ is satisfied - but subjB is not felicitous. SubjB has to have scope not only over the embedded sentential negation, but also over preverbal negative quantifiers in subject position like nimeni (no one) or nici un student (no student) ${ }^{18}$ in examples of the form $x$ believes no $F$ is $G$; due to space limitations, I do not provide the actual data.

\section{Subjunctive $B$ as propositional de se}

In this section, I propose a semantic solution to the problem of deriving the fixed wide-scope of $\operatorname{subjB}$, as opposed to syntactically stipulating the wide-scope and attempting to justify the syntactic assumption on independent grounds. In particular, I assume that subjB can freely scope with respect to negation and I propose that subjB has a third presuppositional component, besides temporal $d e s e^{19}$ and dissociation, which rules out the narrow scope: subjB is also propositional de se, i.e. it presupposes that the proposition expressed by the embedded clause is true in the centered worlds self-ascribed by the attitude holder.

Intuitively, an individually de se report is about an individual that is identical to the beliefinternal 'self' and a temporally $d e$ se report is about a time that includes the belief-internal 'now'. A propositionally de se report is about a proposition that includes the belief-internal 'actually', where the belief-internal 'actually' is the set of worlds self-ascribed by the believer.

The resulting analysis is theoretically appealing because it extends the parallel between pronouns, tenses and moods to de se readings, following the research program of Partee (1973), Abusch (1997), Stone (1999) and Schlenker (2003) among others.

\subsection{Deriving the 'only wide scope' generalization}

The basic idea is that subjB takes wide scope with respect to negation much like the pronominal tense takes wide scope with respect to negation in the well-known example from Partee (1973) I didn't turn off the stove. As Partee (1973): 602 observes, "... such a sentence clearly does not mean that [...] there exists no time in the past at which I turned off the stove". That is, subjB 'goes proxy' for, i.e. it must be bound by, the centered world variable contributed by the attitude verb. This makes it parallel to null PRO, which has to be bound by the belief-internal 'self' variable $x^{\text {self }}$ and to the temporal de se presupposition, which 'goes proxy' for the belief-internal 'now' variable $t^{\text {now }}$.

The basic structure of a propositional de se report is given in (22) below: $w^{*}$ stands for the actual world; in an expression of the form $\lambda w: \phi . \psi, \phi$ is the presupposition and $\psi$ is the assertion; given that we are focusing on the modal coordinate, I use dox instead of self_ascribe and omit the variables $x^{\text {self }}$ and $t^{\text {now }}$ for simplicity.

\footnotetext{
${ }^{18}$ Under the assumption that nimeni (no one) and nici un student (no student) are negative quantifiers exhibiting negative concord with the sentential negation $n u$ and not negative polarity items.

${ }^{19}$ De se interpretations are in general presupposed because they require the presence of a pronominal, hence anaphoric / presuppositional, element - either in the individual or the temporal domain.
} 
Mary believes that she is ( $\operatorname{subjB}-$ propositional de se) not in danger. $\sqrt{ }$ subjB $>>$ not

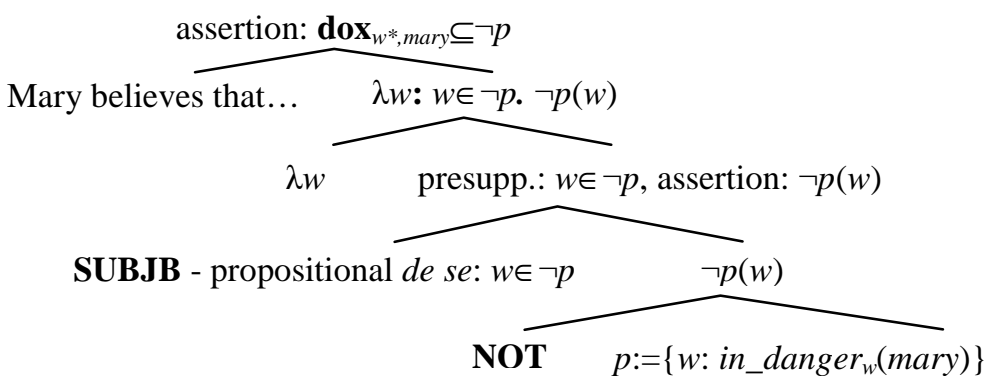

The de se presupposition redundantly iterates the asserted part of the embedded clause. But, as shown in (23) below, the same presupposition yields a contradiction if subjB has narrowscope with respect to negation - thus we derive the 'only wide scope' generalization.

(23) Mary believes that she is (subjB - propositional de se) not in danger. \#not $>>$ subjB

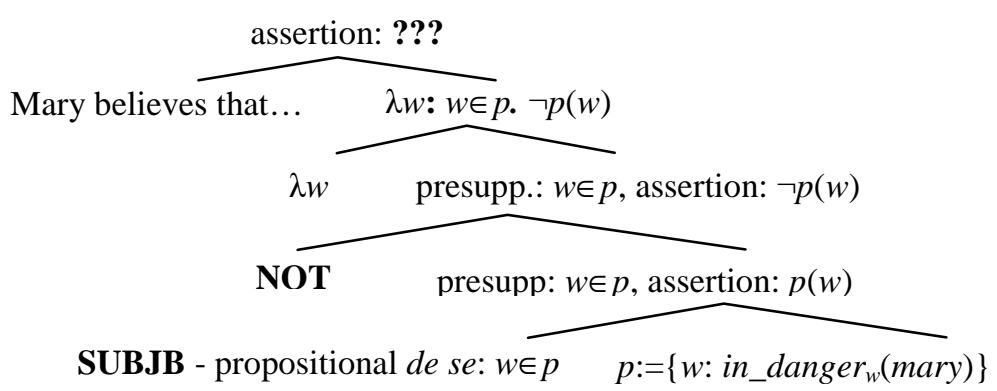

At the embedded clause level, we presuppose that Mary's centered worlds satisfy $p$ and we assert that they do not. But no possible world can satisfy such a condition, hence the belief report ascribes to Mary the empty set of centered worlds which, under the assumption that Mary's beliefs are consistent, is impossible.

It is important to represent and compute the de se presupposition at the level of the embedded clause and not at the matrix clause level, e.g. as the contradiction between the assertion that Mary believes she is not in danger (see $\mathbf{d o x}_{w^{*}, \text { mary }} \subseteq \neg p$ in (22) above) and a presupposition of the form Mary believes she is in danger, i.e. $\mathbf{d o x}_{w^{*}, \text { mary }} \subseteq p$. Representing the presupposition at the matrix level would not make any difference for the embedded negation in (23) above (we still derive a contradiction), but it would predict that a matrix negation is also unacceptable, e.g. in a sentence like It is not the case that Mary believes that $p$, with $p$ marked with subjB. Such a sentence asserts $\neg \mathbf{d o x}_{w^{*}, \text { mary }} \subseteq p$ and, if we represented the de se presupposition at the matrix level, we would have $\mathbf{d o x}_{w^{*}, \text { mary }} \subseteq p$, thus contradicting the assertion. But we know that subjB reports with a matrix negation are felicitous (see (16) above), so we have to represent and bind the propositional de se presupposition locally at the embedded clause level.

The local binding of the presupposition at the embedded clause level is a consequence of the presupposition resolution procedure itself: the de se presupposition contains the bound world variable $w$ and this variable has to still be bound when the presupposition is resolved ${ }^{20}$.

A final observation: the present account of the 'only wide scope' generalization is not entirely appealing insofar the propositional de se presupposition is basically identical to the assertion, which should yield infelicity if we assume something like Stalnaker's non-redundancy constraint on context update (see Stalnaker (1978)). I do not have anything to say about this except to point out that the felicitous sentence The queen of Netherlands exists exhibits a

\footnotetext{
${ }^{20}$ For more discussion, see van der Sandt (1992): 363-366.
} 
similar kind of redundancy: the definite description presupposes the existence of the queen of Netherlands, which is exactly what the sentence asserts ${ }^{21}$.

\subsection{The incompatibility between subjunctive $B$ and probabil}

The contrast between subjB and indicative belief reports with probabil is exemplified in (24).

(24) $x$ believes that probably $p$

VIND; \#SUBJB

Cînd m-am întîlnit cu el, Ion credea că... (When I met him, John believed that...)

a. marțienii probabil invadează Bucureştiul. the Martians probably invade.ind.pres Bucharest.

b. \#marțienii probabil ar invada Bucureştiul. the Martians probably subjB invade Bucharest. ...the Martians were probably invading Bucharest.

\#SUBJB

Intuitively, subjB is incompatible with probabil reports precisely because, being propositionally de se, subjunctive $\mathrm{B}$ expresses that the attitude holder is completely committed to the believed proposition, while probably implicates that there is at most a partial commitment.

To make this intuition precise, we need to look more closely at how probably is interpreted. Imagine that Mary utters the sentence in (25) below while walking through a bad neighborhood late at night. I will represent this sentence as shown in (26).

(25) I'm probably in danger. (26) MOST $\left(\left\{w: w \in \mathbf{d o x}_{w^{*}, \text { mary }}\right\}\right)(\{w:$ in_danger $(\operatorname{mary})\})$

The adverb probably is an epistemic modal quantifier, i.e. it quantifies over Mary's doxastic alternatives $\mathbf{d o x}_{w^{*}, \text { mary }}$ (where $w^{*}$ is the actual world). In fact, we consider only a subset of $\mathbf{d o x}_{w^{*}, \text { mary }}$, namely the worlds that are ideal - or close enough to being ideal - with respect to a stereotypical ordering source ('in view of what Mary takes the normal course of events to $\mathrm{be}^{\prime 22}$ ), but for simplicity I will assume that (25) is true iff most of Mary's doxastic alternatives $w$ are such that Mary is in danger in $w$. Since probably is a 'MOST'-type quantification, it has a 'ᄀEVERY'-type scalar implicature, i.e. $\neg \operatorname{EVERY}\left(\mathbf{d o x}_{w^{*}, m a r y}\right)\left(\left\{w\right.\right.$ : in_danger in $\left.\left.\left._{\text {mary }}\right)\right\}\right)$,

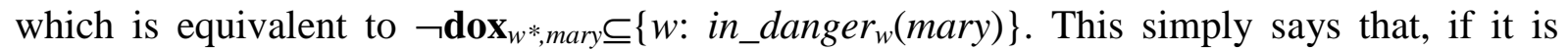
probable that $p$, then it is not certain that $p$.

The goal is to derive a contradiction between the propositional de se presupposition, which requires the complete commitment of the attitude holder, and the implicature triggered by probabil / probably, which denies the complete commitment. At a first glance, pursuing this strategy does not seem to take us too far: even if we were able to derive a contradiction, we would expect the implicature to be canceled since, by definition, implicatures are only default inferences. However, implicatures of this kind, i.e. which contradict presuppositions, always yield infelicity, despite their otherwise undisputed cancelability. This is shown by the pairs of sentences in (27)-(28), (29)-(30) and (31)-(32) below: the presuppositions triggered by stop in (27) and (29) and by the fact that the quantifier restrictor itself is presupposed in (31) contradict the implicatures of probably and most, making the examples unacceptable.

(27) \#The students that stopped smoking had probably smoked before.

(28) VThe students that stopped smoking had smoked before.

(29) \#Most students that stopped smoking had smoked before.

(30) $\sqrt{ }$ Every student that stopped smoking had smoked before.

\footnotetext{
${ }^{21}$ I am grateful to Philippe Schlenker (p.c.) for pointing out this type of examples.

${ }^{22}$ See Kratzer (1991): 643-645.
} 
(31) \#Most dolphins are dolphins.

(32) $\sqrt{\text { Every dolphin is a dolphin }}{ }^{23}$.

Now consider (33) below and assume for the moment that subjB scopes under probabil.

(33) \#Mary believes that she probably is (subjB - propositional de se) in danger.

The 'subjB narrow-scope' reading is interpreted as shown in (34) below. Just as in (23) above, subjB contributes a propositionally de se presupposition. Then, we have the asserted probably quantification. Finally, the formula following the semi-colon is the probably implicature. Generally, in an expression of the form $\lambda w: \phi . \psi ; \xi, \phi$ is the presupposition, $\psi$ is the assertion and $\xi$ is the implicature. Following the observations in Chierchia (2001): 5 et seqq., we compute the scalar implicature at the embedded clause level.

\section{believe $_{w^{*}}\left(\right.$ mary, $\lambda w:$ in_danger ${ }_{w}($ mary $)$.}

$\operatorname{MOST}\left(\mathbf{d o x}_{w, \text { mary }}\right)\left(\left\{w^{\prime}:\right.\right.$ in_danger $_{w^{\prime}}($ mary $\left.\left.)\right\}\right) ; \neg \mathbf{d o x}_{w, \text { mary }} \subseteq\left\{w^{\prime}:\right.$ in_danger $_{w^{\prime}}($ mary $\left.\left.)\right\}\right)$

There is no intuitively plausible way to derive a contradiction between the presupposition and the implicature in (34). Quite the contrary: the presupposition that Mary is in danger in $w$ (i.e. in_danger $($ mary $)$ ) and the implicature that it is not the case that Mary believes in $w$ that she is in danger (i.e. $\neg \mathbf{d o x}_{w, m a r y} \subseteq\left\{w^{\prime}:\right.$ in_danger $_{w}\left(\right.$ mary $\left.\left._{\text {a }}\right\}\right)$ can very well be compatible - people often refuse to believe things that are actually true. Intuitively however, we should be able to derive a contradiction between the presupposition and the implicature: we presuppose that all of Mary's doxastic alternatives satisfy the proposition $p:=\left\{w^{\prime}:\right.$ in_danger $_{w^{\prime}}\left(\right.$ mary $\left._{\text {) }}\right\}$ (this is what the formula believe $w^{*}($ mary $, \lambda w: p(w)$... says) and we implicate that they do not.

\subsection{Propositional de se all the way: centered propositions}

To solve the probabil - subjB puzzle, I propose to replace centered worlds with centered propositions, i.e. triples of the form $\left(p, f^{\text {self }}, g^{\text {now }}\right)$, where $f^{\text {self }}$ is an individual concept (type $s e$ ) and $g^{\text {now }}$ is a time-interval concept (type $\left.s \tau\right)$. Intuitively, for any $w \in p, f^{\text {self }}(w)$ is the beliefinternal 'self' in $w$ and $g^{\text {now }}(w)$ is the belief-internal 'now' in $w$. It is a natural assumption that there is a unique 'self' and a unique 'now' per belief-world $w$, although they can vary from world to world as in, for example, Heimson believes that he is Hume or Napoleon.

Note that we independently need centered propositions to account for cross-sentential propositional anaphora in examples like (35) below.
${ }^{1}$ Maria crede că Ion ar fi chipeş.
${ }^{2}$ Ar avea ochi frumoşi.
Mary believes that John is (subjB) handsome. He has (subjB) beautiful eyes.

The subjB sentence $\left(35^{2}\right)$ has to be interpreted as a further elaboration of Mary's beliefworlds $^{24}$ and cannot be interpreted as stating that John has beautiful eyes in the actual world.

The core idea of the centered-propositions analysis is that, in a belief report of the form $x$ believes + embedded clause, the matrix clause $x$ believes sets up the context for the interpretation of the embedded clause by contributing a centered proposition relative to which the embedded clause is interpreted. Of course, as (35) above shows, a subsequent matrix clause can also be interpreted relative to the same centered proposition. The matrix clause basically introduces a centered proposition discourse referent (more exactly, three suitably related discourse referents - for $p, f^{\text {self }}$ and $g^{\text {now }}$ ), which is anaphorically accessed by the embedded clause. For simplicity, we will represent this via static existential quantification

\footnotetext{
${ }^{23}$ I am grateful to Roger Schwarzschild for suggesting the examples in (31) and (32).

${ }^{24}$ We can even have modal subordination, as shown in (i) below.

(i) Maria crede că ar fi vampiri în LA. $\quad{ }^{2} \mathbf{A r}$ intra noaptea în case şi ar ataca oamenii în somn. Mary believes that there are (subjB) vampires in LA. They break (subjB) into houses at night and attack (subjB) people in their sleep.
} 
over a propositional variable $p$ that is contributed by the attitude verb (we systematically ignore $f^{\text {self }}$ and $g^{\text {now }}$ ). For example, a simple report like Mary believes that she is in danger is represented as shown in (36) below.

$$
\begin{aligned}
& \left.\exists p \text { (believe } w^{*}(\text { mary, } p) \& \text { in_danger }(\text { mary })\right) \text {, where: }
\end{aligned}
$$

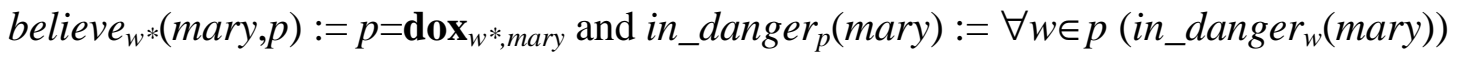

The first conjunct equates the proposition $p$ with Mary's doxastic alternatives in the actual world $w^{*}$. The second conjunct simply says that for any world $w$ in the proposition $p$, Mary is in danger in $w$. This technique of encapsulating modal quantification was first proposed in Stone (1999) and it is independently motivated by the analysis of modal subordination.

A propositional de se report is interpreted as in (37) below. The second conjunct is the propositional de se presupposition contributed by subjB. For simplicity, I do not distinguish between the status of assertions and presuppositions or implicatures. Just as in (36), the third conjunct is the assertion contributed by the embedded clause.

$$
\begin{aligned}
& \text { Mary believes that she is (subjB - propositional de se) in danger. } \\
& \exists p\left(p=\mathbf{d o x}_{w^{*}, \text { mary }} \& p \subseteq\{w: \text { in_danger }\right. \\
& \text { (mary) }\} \text { \& in_danger } \\
& \text { (mary }))
\end{aligned}
$$

The solution to the 'only wide-scope' problem in $\mathbf{4 . 1}$ above is easily reformulated in terms of centered propositions. Negation is interpreted as: $\operatorname{not}_{w}\left(p^{\prime}\right):=w \notin p^{\prime} ; \operatorname{not}_{p}\left(p^{\prime}\right):=\forall w \in p\left(w \notin p^{\prime}\right)$. That is, negation is interpreted as any other lexical predicate (e.g. in_danger) modulo the fact that it has a propositional argument. We give only the interpretation of the contradictory narrow-scope subjB (not>>subjB): the second conjunct (the propositional de se presupposition) contradicts the third conjunct (the assertion).

(38) Mary believes that she is (subjB - propositional de se) not in danger.

$$
\exists p\left(p=\operatorname{dox}_{w^{*}, \text { mary }} \& p \subseteq\left\{w: \text { in_danger }{ }_{w}(\text { mary })\right\} \& \operatorname{not}_{p}\left(\left\{w: \text { in_danger }_{w}\left(\text { mary }_{)}\right\}\right)\right)\right.
$$

Moreover, since the existential quantification over the variable $p$ is contributed by the attitude verb believe, we are still locally representing and binding the propositional de se presupposition, ruling out the narrow-scope of subjB with respect to the embedded negation while at the same time allowing for felicitous matrix negation examples like (16) above.

\subsection{Deriving the incompatibility between subjunctive $B$ and probabil}

Finally, we return to the probabil problem, i.e. to ruling out the 'subjB narrow-scope' reading (probabil >>subjB) of (33) above. This is interpreted as shown in (39).

$$
\begin{aligned}
\exists p( & p=\mathbf{d o x}_{w^{*}, \text { mary }} \& p \subseteq\{w: \text { in_danger }(\text { mary })\} \& \\
& \forall w^{\prime} \in p\left(\operatorname{MOST}\left(\mathbf{d o x}_{w^{\prime}, m a r y}\right)\left(\left\{w: \text { in_danger }{ }_{w}(\text { mary })\right\}\right)\right) \& \\
& \left.\forall w^{\prime} \in p\left(\neg \mathbf{d o x}_{w^{\prime}, m a r y} \subseteq\left\{w: \text { in_danger }{ }_{w}(\text { mary })\right\}\right)\right)
\end{aligned}
$$

The second conjunct is the propositional de se presupposition, the third conjunct is the probably assertion and the last conjunct is the probably implicature. The advantage of using centered propositions instead of centered worlds is that now we have access to the first conjunct contributed by the attitude verb when we compute the contradiction between the presupposition and the implicature. Given the equality in the first conjunct, the presupposition is equivalent to the formula in (40a) below and the implicature with the formula in (40b).

$$
\begin{aligned}
& \text { a. presupposition: } \mathbf{d o x}_{w^{*}, \text { mary }} \subseteq\{w: \text { in_danger } \\
& \text { b. implicature: } \forall w^{\prime} \in \mathbf{d o x}_{w^{*}, \text { mary }}\left(\neg \mathbf{d o x}_{w^{\prime}, \text { mary }} \subseteq\left\{w: \text { in_danger }_{w}(\text { mary })\right\}\right)
\end{aligned}
$$


To derive the contradiction between (40a) and (40b), we only need the (fairly uncontroversial) belief 'introspection ${ }^{\prime 25}$ principles in (41a) and (41b) below. The 'introspection' principles are equivalent to the formula in (41c), which exhibits the internal structure of the dox function that is enforced by these principles.

$$
\begin{aligned}
& \text { a. Positive 'Introspection': bel }(x, p) \rightarrow \text { bel }(x, \text { bel }(x, p)) \\
& \text { b. Negative 'Introspection': } \neg \text { bel }(x, p) \rightarrow \text { bel }(x, \neg \text { bel }(x, p))^{26} \\
& \text { c. } \forall w \forall x \forall w^{\prime} \in \mathbf{d o x}_{w, x}\left(\mathbf{d o x}_{w^{\prime}, x}=\mathbf{d o x}_{w, x}\right)^{27}
\end{aligned}
$$

Among other things, the 'introspection' principles derive the intuitive equivalence between sentence (25) above when uttered by Mary and the belief report Mary believes that she is probably in danger, when probably is interpreted relative to Mary's doxastic alternatives.

It is easily checked that, based on (41c), we can derive a contradiction between the formulas in (40a) and (40b) above. To derive the incompatibility between subjunctive B and probabil, we also need to rule out the 'wide scope' reading $\mathbf{s u b j B}>>$ probabil. I propose that this is due to the fact that dissociation yields a contradiction in this case. The dissociation presupposition is provided in (42a) below and the corresponding assertion in (42b).

\#Mary believes that she probably is (subjB - dissoc.) in danger. \#subjB >>probabil

a. dissociation: $\exists w \in \mathbf{C S}\left(\neg \operatorname{MOST}\left(\mathbf{d o x}_{w, \text { mary }}\right)\left(\left\{w^{\prime}:\right.\right.\right.$ in_danger $_{w^{\prime}}($ mary $\left.\left.\left.)\right\}\right)\right)$

b. assertion: $\forall w^{\prime \prime} \in \mathbf{C S}\left(\mathbf{d o x}_{w^{\prime \prime}, \text { mary }} \subseteq\left\{w^{\prime \prime \prime}: \operatorname{MOST}\left(\mathbf{d o x}_{w^{\prime \prime}, \text { mary }}\right)\left(\left\{w^{\prime}:\right.\right.\right.\right.$ in_danger $_{w^{\prime}}($ mary $\left.\left.\left.\left.)\right\}\right)\right\}\right)$

Take a witness world $w^{*} \in \mathbf{C S}$ that satisfies the dissociation requirement; hence, we have that $\neg \operatorname{MOST}\left(\operatorname{dox}_{w^{*}, \text { mary }}\right)(p)$, where $p$ is the proposition $\left\{w^{\prime}:\right.$ in_danger $w^{\prime}\left(\right.$ mary $\left.\left.^{\prime}\right)\right\}$. This world should also satisfy the assertion, i.e. $\operatorname{dox}_{w^{*}, \text { mary }} \subseteq\left\{w^{\prime \prime \prime}: \operatorname{MOST}\left(\mathbf{d o x}_{w^{\prime \prime \prime}, \text { mary }}\right)(p)\right\}$. The latter formula is equivalent to $\forall w^{\prime \prime \prime} \in \mathbf{d o x}_{w^{*}, \text { mary }}\left(\operatorname{MOST}\left(\mathbf{d o x}_{w^{\prime \prime}, \text { mary }}\right)(p)\right)$. By the introspection postulate in (41c), this formula is equivalent to $\operatorname{MOST}\left(\operatorname{dox}_{w^{*}, \text { mary }}\right)(p)$, which contradicts the dissociation requirement. A final observation: the dissociation-based analysis of the infelicity of the widescope structure subjB>>probabil makes the prediction that, if subjB dissociates from a set of worlds that is different from the worlds in which the belief is reported, we will not get a contradiction between assertion and dissociation - hence, in such belief reports, there should be no contrast between indicative and subjB and the latter should be compatible with embedded probabil. As the example in (43) below shows, this prediction is borne out.

Maria nu încearcă să îl pună pe Ion în umbră şi nu vrea ca Ion să creadă că...

Mary is not trying to disadvantage John and she doesn't want John to believe that...

probabil ar încerca să facă asta.
probably subjB try subjA do this.
she is probably trying to do this.

\section{Conclusion}

I have analyzed the Romanian subjB as a single package of three distinct presuppositions: temporal de se, dissociation and propositional de se. The subjB - indicative contrast is the temporal analogue of the PRO - overt pronoun contrast in the individual domain. The dissociation presupposition enabled us to show that subjB always takes scope over the

\footnotetext{
${ }^{25}$ The scare quotes are meant to suggest that the one should not understand the introspection principles as psychological principles; for more discussion, see Hintikka (1962): 56-57 et seqq, who prefers the less psychological term of 'self-intimating'.

${ }^{26}$ The logic of belief is usually assumed to be the modal system KD45, where positive 'introspection' is Axiom 4 $\left(B_{x} \phi \rightarrow B_{x} B_{x} \phi\right)$ and negative 'introspection' is Axiom $\mathbf{5}\left(\neg B_{x} \phi \rightarrow B_{x} \neg B_{x} \phi\right)$.

${ }^{27}$ The de se version of the introspection postulate is given in (i) below. We use the simpler dox-based version.

(i) $\forall w, x, t \forall\left(w^{\prime}, x^{\prime}, t^{\prime}\right) \in$ self_ascribe $_{w, x, t}\left(\right.$ self_ascribe $_{w^{\prime}, x^{\prime}, t^{\prime}}=$ self_ascribe $\left._{w, x, t}\right)$.
} 
embedded negation. The propositional de se presupposition derives this generalization. The move to centered propositions (generalizing centered worlds) in combination with propositional de se, 'introspection' principles and dissociation conspire to derive the fact that subjB reports (unlike their indicative counterparts) are infelicitous with embedded probabil.

There are at least two directions for future research. First, we need to investigate the distribution and interpretation of subjB and its contrast with indicative when the two moods are embedded under other attitude verbs, e.g. spune (say), zice (say), pretinde (claim) and se indoi (doubt). Moreover, following Farkas (1992), we need to extend the investigation to the Romanian subjunctive A and the ways it contrasts with indicative and subjB. Second, we need to examine the cross-linguistic typological predictions that the present analysis of subjB suggests. An important question is whether the three components of the subjB interpretation are truly independent; if so, we expect to encounter languages with items that have only one or two of the three presuppositions. A possibly relevant mood is the English infinitive: it is compatible with verbs like hope or promise, which suggests that it is not temporally de se, and it is incompatible with probably (\#Mary believes herself to probably be in danger vs. Mary believes that she is probably in danger), which might indicate that it is propositionally de se.

\section{References}

Abusch, D.: 1997. Sequence of Tense and Temporal De Re, in Linguistics \& Philosophy 20, $1-50$.

Chierchia, G.: 1989. Anaphora and Attitudes De Se, in Semantics and Contextual Expression, R. Bartsch et al. (eds.), Foris, 1-31.

Chierchia, G.: 2001. Scalar Implicatures, Polarity Phenomena, and the Syntax/Pragmatics Interface, U. of Milan - Bicocca ms., May 2001.

Cresswell, M.J. and A. von Stechow: 1982. De Re Belief Generalized, in Linguistics and Philosophy 5, 503-535.

Farkas, D.: 1992. On The Semantics of Subjunctive Complements, in Romance Languages and Modern Linguistic Theory, P. Hirschbühler et al (eds.), Benjamins, 69-104.

Heim, I.: 1992. Presupposition projection and the semantics of attitude verbs, in Journal of Semantics 9, 183-221.

Hintikka, J.: 1962. Knowledge and Belief, Cornell University Press.

Hintikka, J.: 1969. Semantics for Propositional Attitudes, in Philosophical Logic, J.W. Davis et al (eds.), 21-45.

Kamp, H. \& U. Reyle: 1993. From Discourse to Logic, Kluwer.

Kaplan, D.: 1989. Demonstratives, in Themes from Kaplan, P. Almog et al (eds.), OUP, 481563.

Kratzer, A.: 1991. Modality, in Semantik/Semantics, A. von Stechow et al (eds.), de Gruyter, 639-650.

Lewis, D.: 1979. Attitudes De Dicto and De Se, in The Philosophical Review 88:4, 513-543. 
Partee, B.: 1973. Some Structural Analogies between Tenses and Pronouns in English, in Journal of Philosophy 70, 601-609.

Potts, C.: 2004. Conventional Implicatures, A Distinguished Class of Meanings, to appear in The Oxford Handbook of Linguistic Interfaces, G. Ramchand et al (eds.), OUP.

Schlenker, P.: 2003. A plea for monsters, in Linguistics and Philosophy 26, 29-120.

Searle, J.: 1983. Intentionality. An Essay in the Philosophy of Mind, Cambridge.

Stalnaker, R.: 1978. Assertion, in Syntax and Semantics 9, 315-332.

Stone, M.: 1999. Reference to Possible Worlds, RuCCS Report 49, Rutgers University NB.

Van der Sandt, R.: 1992. Presupposition Projection as Anaphora Resolution, in Journal of Semantics 9, 333-377. 